Vanesa Matajc

\title{
Literatura in elektronska komunikacija: intermedialnost sodobnega romana
}

\begin{abstract}
Ključne besede: intermedialnost, elektronska komunikacija, postmoderni roman, pripovedni komunikacijski model, Daniel Glattauer
\end{abstract}

\section{Medij, medialnost in literatura}

Pojem medij je po Rolandu Posnerju ${ }^{1}$ mogoče opredeliti v štirih osnovnih pomenih: 1) s fiziološkega vidika, v katerem je medij čutni modus komunikacije, npr. vizualni, avditivni, olfaktivni, taktilni modus oziroma njihovo intermedialno razmerje; 2) s fizičnega vidika, v katerem je medij snov, iz katere se ustvarja umetnina, npr. jezik, barva, ton, kamen itn.; 3) s tehnološkega vidika, v katerem je medij "sredstvo posredovanja med znakovno proizvodnjo in potrošnjo«, npr. računalniški zaslon, fotografija, radio, oralnost, pisnost oziroma njihovo intermedialno razmerje; 4) s sociološkega vidika, v katerem je medij institucionalno-organizacijski okvir komunikacije, npr. politika, znanost, gospodarstvo itn. (prim. Biti, 2000, 302).

Predvsem prvi, drugi in tretji vidik razumevanja pojma medij postanejo pomembni za tisti sklop sodobne literature, ki se sicer ustvarja in prezentira $\mathrm{v}$ (fizično gledano) mediju jezika, obenem pa se očitno nanaša na sodobni (v tehnološkem vidiku opredeljeni) medij interneta in, ožje, računalniškega zaslona. S fiziološkega vidika pa gre torej za vizualni modus komunikacije, ki je lahko tudi v intermedialnem razmerju $\mathrm{z}$ avditivnim modusom. Ta vrsta komunikacije je elektronska. Kot pove že oznaka, jo v širšem tehnološkem smislu omogoča celota obstoječih elektronskih medijev, v ožjem pa zaslon, npr. računalniški zaslon ali zaslon mobilnega telefona.

Osnovni predmet pričujoče razprave bo sodobni roman, ki se nanaša na e-poštno komunikacijo kot enega najpogostejših načinov sodobne vsakdanje komunikacije. „Citiranje« sodobne zasebne tovrstne komunikacije se sicer pojavlja v literarni nadvrsti lirika (SMS poezija), kot postopek potujitve odrske iluzije jo je mogoče vnesti tudi v dramsko skripcijo, namenjeno gledališki uprizoritvi, najočitnejše - in to ne brez razloga - pa je to »citiranje« v pripovedništvu, ki vzpostavlja poseben, pripovedni komunikacijski model s štirimi ravnmi (okvirji) komunikacije. Izhajajoč

$1 \quad$ V razpravi »Nonverbale Zeichen in öffentlicher Kommunikation« v Zeitschrift für Semiotik 3, 1985. 
iz McLuhanove znamenite teze, da je medij sporočilo, se literarni teoriji, ko skuša opredeliti sodobno pripovedništvo in posebej roman, s tem odpira vprašanje o vplivu medija na literarno sporočilo, o intermedialni specifiki tovrstnega sodobnega romana ter o razmerju med intermedialnostjo in intertekstualnostjo.

Sodobna literarna teorija pogosto izhaja iz predpostavke o medbesedilni »naravi« besedil in tako literaturo opredeljuje kot poseben tip diskurza, ki se nanaša na druge, neliterarne diskurze (Johansen, 2002). ${ }^{2}$ Ti so $\mathrm{z}$ vidika medija kot čutnega modusa lahko posredovani vizualno, v fizičnem vidiku medija kot pisava, ali pa avdialno, kot govorjeni jezik. S tehnološkega vidika je medij pri tem oralnost ali knjiga oziroma knjižni natis.

Ko se literatura medbesedilno nanaša na druge, neliterarne diskurze, $\mathrm{z}$ vidika tipologije medialnosti (Rajewsky, 2002) pripada tipu intramedialnosti: medbesedilnost se pri tem vzpostavlja v polju istega medija. S fiziološkega vidika medija gre najpogosteje za vizualni čutni modus, ki se v tehnološkem vidiku medija najpogosteje konkretizira kot knjiga oziroma natisnjeni zapis jezikovnega sporočila. $\mathrm{Z}$ vidika medija kot snovi pa gre pri tem za medij jezika, ki je lahko konkretiziran bodisi kot (natisnjeni) zapis oziroma pisava bodisi kot govor, tj. avditivno zaznavna oralnost. Tudi če se (knjižno natisnjena) literatura nanaša na neliterarne diskurze iz polja govorjenega, tj. nezapisanega jezikovnega sporočanja, se njena medbesedilna »narava«, vsaj z vidika medija kot snovi, še vedno vzpostavlja v istem mediju, v jeziku, torej gre za intramedialnost.

S tehnološkega vidika medija pa se ta osnovna, literarno-medbesedilna intramedialnost razceplja še $\mathrm{v}$ dve drugi možnosti, namreč $\mathrm{v}$ transmedialnost in intermedialnost.

\section{Literatura, elektronski mediji, internet, e-poštna komunikacija}

S tehnološkim razvojem v obdobju modernosti oziroma $\mathrm{z}$ iznajdbami tedaj novih (množičnih) medijev (radio, časopis, televizija itn.) se je bistveno povečal obseg možnosti za prenos/formiranje sporočila, in sicer tudi tako, da »izvornega (fiziološko razumljenega) medija, kot je npr. vizualni čutni modus, ni bilo več mogoče prepoznati. To seveda ni ekskluzivna inovacija 20. stoletja, je pa v obdobju pozne modernosti posebej očitna (npr. z množičnim medijem televizije). Tovrstni nerazdružljivi spoji zlasti vizualnega in zvočnega zapisa $\mathrm{z}$ vidika tipologije medialnosti ustvarjajo tip transmedialnosti. V obdobju postmoderne pa je razmah elektronskih medijev in digitalnega zapisa omogočil povsem nove spoje oziroma možnosti transmedialnosti,

2 Za slovenski prevod pojmovnika gl. Juvan (2006, 53-54). 
na področju umetnosti pogosto po principih "estetike performativnosti «. ${ }^{3}$ Performativnost sodobne literature, ki jo omogočajo tudi transmedialne inovacije, nedvomno spodbujajo multimediji ${ }^{4} \mathrm{z}$ digitalno možnostjo zapisa. A celo tisti del sodobne natisnjene pripovedne literature, ki se nanaša na elektronsko komunikacijo, svojo specifiko zarisuje s selektivno uporabo principov estetike performativnosti. Med drugim tako, da enega njenih osrednjih principov, tj. princip telesnosti oziroma prezenco realnega telesa, akterja $\mathrm{v}$ realnem prostoru, uporabi per negationem: ${ }^{5}$ popolnoma ga zanika in ga popolnoma nadomesti $\mathrm{z}$ virtualnostjo akterja (pripovednega lika) $\mathrm{v}$ virtualnem prostoru, ki je značilen sodobni prostor komunikacijskega stika. Vsekakor pa $\mathrm{z}$ nanašanjem na performativnost komunikacije ta sodobna literatura konfrontira svoj pripovedni komunikacijski model $\mathrm{z}$ dramskim in $\mathrm{s}$ tem stopnjuje dramatičnost ${ }^{6}$ literarnega sporočila.

Če gre v sodobni pripovedni literaturi, ki »citira« elektronsko komunikacijo, z vidika medija kot snovi še vedno za prvi tip medialnosti, tj. za intramedialnost (saj jo medbesedilna »narava« literature opredeljuje kot nanašanje na neliterarne diskurze, bodisi iz polja zapisanih/natisnjenih bodisi iz polja govorjenih sporočil), pa gre $s$ tehnološkega vidika medija pri tem že za tretji tip medialnosti, tj. za intermedialnost. Kriterij tega tipa je, da je v intermedialnem proizvodu še vedno mogoče prepoznati »izvorni medij« oziroma je ta celo dominanten: ko govorimo o tem sklopu sodobne literature, v njej vsekakor prevlada knjižni medij natisnjenega zapisa. Vendar pa se njegovo sporočilo prezentira kot »citat« sporočila, posredovanega v (tehnološkem) mediju računalniškega zaslona:»citira « torej elektronsko komunikacijo, katere specifiko vzpostavlja prav tehnološki medij zaslona oziroma v širšem smislu elektronski mediji. Sodobni roman, ki »citira« tovrstno e-poštno komunikacijo kot enega najpogostejših

3 Skopo povzeto, gre za novo dojemanje umetniškega dela, katerega »obstoj ni več neodvisen od producenta in prejemnika«; ki obstaja iz »dogodka, ki vključuje /.../ vse« in kjer »produkcija in recepcija potekata $\mathrm{v}$ istem času in $\mathrm{v}$ istem prostoru « (Fischer-Lichte, 2008, 23).

4 Značilen postmoderni tip transmedialnosti je npr. pesniški performativ, ki se dogaja kot projekcija digitalnega avdio-vizualnega zapisa. Projekcija ima performativni značaj zato, ker je zaporedje njenih posameznih delov načeloma nestabilno, spremenljivo, poljubno zamenljivo, s to (vsakokrat »ireverzibilno«) dogodkovnostjo pa zabrisuje svoj reprezentacijski »značaj« in ga nadomešča z (vsaj na videz) neposredno prezentativnostjo, kot da uprizoritev poistoveti z vsakokratno predstavo. $S$ tem se močno navezuje na gledališče, vendar z vidika poznomoderne in postmoderne »estetike performativnosti«.

5 Pri »estetiki performativnosti« se "prezenca« nanaša na igralčevo fenomenalno (in ne semiotično) telo: »Prezenca se /.../ zgodi kot intenzivno izkustvo navzočnosti«, namreč akterjevega delujočega telesa v prostoru (Fischer-Lichte, 2008, 157). V romanu, ki »citira« e-poštno komunikacijo, pa so pripovedovalec, bralec in pripovedne osebe navzoči $\mathrm{v}$ dogajalnem trenutku virtualnega prostora, torej je telesna prezenca scela ukinjena, nadomeščena $\mathrm{z}$ zgolj znakovno prisotnostjo v posredovanju digitalnega zapisa.

6 »Dramatično je načelo gradnje dramskega besedila /.../, ki sporoča o napetosti prizorov in epizod fabule proti razpletu /.../«. (Pavis, 1997, 144) Na moralni ravni pa je dramatično: »akt volje, iz katerega izhajajo navzkrižja, spori, boji« (Vladimir Kralj, nav. po: Kralj, 1998, 19). V romanu, ki »citira« e-komunikacijo, bo »akt« volje zaobsegel le govorno dejanje. 
načinov sodobne vsakdanje komunikacije, svojo specifiko dobiva prav s tem, da svojo osnovno, literarno, tj. (snovno-medijsko, jezikovno, medbesedilno) intramedialnost nadgrajuje $\mathrm{z}$ intermedialnostjo.

Te intermedialno vzpostavljene literarne »mimesis« e-poštne ali internetnoklepetalniške komunikacije pa ne kaže zamenjevati $\mathrm{z}$ načelno transmedialnostjo internetnega medija, ki zaznamuje čisto drugačen tip literature: po Strehovcu (2007, 7) gre za »digitalno literaturo«. Ta pa se po strukturi svojega literarnega sporočila (namreč $\mathrm{z}$ vidika vprašanja, koliko je njegova besedilna struktura zaznamovana $\mathrm{s}$ tradicionalnim (knjižnim) tiskanim medijem in koliko s sodobnim internetnim medijem) dodatno razceplja v dva osnovna modela, ki ju Florian Hartling $(2009,201)$ poimenuje »literatura na internetu« in »internetna literatura «. Prvo manj in drugo bolj oziroma že odločilno zaznamuje internetna opcija principa hiperteksta.

»Internetna literatura« ne označuje zgolj preprostega prenosa literarnega sporočanja iz (knjižno) tiskanega medija in, širše, pisave, ki sukcesivno nosi razvijanje sporočila v časovno-finalnostno in dokončno obliko, saj s tem ne bi omogočala inovacije v principu transmedialnosti. Te skrajnosti pa ne aktivira »literatura na internetu «, ki lahko pri prenosu v njej »nelastni«, internetni medij le tega uporablja zgolj kot širši radij distribucije (Hartling, 2009, 201) in skuša pri tem ohraniti primarno medialnost sporočila, tj. pogoje (knjižnega) natisa zapisa: tu je strukturacija literarnega besedila še vedno hierarhično organizirana oziroma hoče delovati kot stabilni »izvor « opomenjanja po »enosmerni « poti v časovno-finalnostno in dokončno obliko literarnega sporočila, kakršno v principu določa nadzor avtorja kot »izvora «, ${ }^{7}$ predvideva pa jo že »idealni avtor «, kot ga vzpostavlja sama besedilna struktura. ${ }^{8}$ (Z vidika medija so tovrstna, zgolj premeščena literarna besedila torej še vedno vključena $v$ paradigmo modernosti, ki jo vodi časovnost, in ne $\mathrm{v}$ postmoderno paradigmo simultanosti oziroma (virtualno-) prostorske prezence.)

Med obema možnostima »digitalne literature« je »literatura na internetu« bližje tisti sodobni (knjižno natisnjeni) pripovedi, ki svoje literarno sporočilo strukturira kot $\mathrm{v}$ osnovi intramedialno medbesedilno, v nadgradnji pa kot intermedialno nanašanje na e-poštno komunikacijo oziroma na internetne klepetalnice. Tovrstna (knjižno

7 Premestitev literarnega sporočila v drug, internetni medij vsekakor odpre možnost, da bralec "prekrši dogovor « oziroma aktivira transmedialno »branje/proizvajanje« tega literarnega sporočila. To omogoča potencialno neskončna mrežnost virtualnega prostora: besedilo literarnega sporočila se resda prezentira v središčnem prostoru zaslona, to prostorsko besedilno središče pa obdajajo - in razpršujejo - potencialno neskončne in poljubne možnosti povezav na druga (literarna in neliterarna) jezikovna besedila, na likovna in glasbena »besedila « ter na vizualno-avdialne transmedialne spoje. Četudi »literatura na internetu« torej s strukturacijo literarnega besedila načeloma ne predvideva tovrstnega, skrajno performativnega branja, ga novi (internetni) medijski pogoji vsaj omogočajo.

8 Avstrijska pisateljica Elfriede Jelinek je na svoji spletni strani objavila roman Zavist (Neid) prav z argumentom avtorske svobode pri tržni distribuciji romana. 
natisnjena) literatura prav z nanašanjem na sebi nelasten medij problematizira sodobno komunikacijo in medčloveška razmerja, in sicer tako, da skozi svojo intermedialnost konfrontira pripovedni in dramski komunikacijski model.

\section{Pripovedni in dramski komunikacijski model v intermedialnem razmerju do e-poštne komunikacije}

Specifiko tistih sodobnih romanov, ki se nanašajo na e-poštno komunikacijo (ali tudi na internetne klepetalnice, kot npr. v romanu Viktorja Pelevina Čelada groze, Шлем Ужаса (Миф о Тесее и Минотавре), 2006), opredeljuje medčloveška komunikacija kot osrednja tema teh romanov. Ko roman čim dosledneje »citira« obe omenjeni vrsti sodobne komunikacije, vzbuja »odrsko iluzijo« neposredne prezentacije medčloveške komunikacije. Zato pripovedni komunikacijski model teh romanov vzbuja vtis, da je nadomeščen z dramskim komunikacijskim modelom, pri Platonu opredeljenim kot mimetični način izrekanja, ${ }^{9}$ kar zarisuje najočitnejšo specifiko teh sodobnih romanov. ${ }^{10}$

Pripovedni in dramski komunikacijski model je teoretsko razločila semiotika. Po Manfredu Pfistru (1977, povzeto po ponatisu 1988) razliko vzpostavljajo govorni položaji: prikazane dramske osebe - in njihov govor - so neposredno soočene s prejemnikom dramskega teksta oziroma jih ta neposredno sliši, prejemniku pripovednega teksta pa so prikazane pripovedne osebe in njihov govor posredovane $\mathrm{z}$ intervencijo pripovedovalca, ki izdeluje pripovedovano resničnost - pri izdelavi imaginarnega prostora vodi prejemnika pripovednega teksta oziroma bralca šele pripovedno posredništvo pripovedovalca. V primerjavi pripovednega in dramskega komunikacijskega modela se izkaže, da si delita notranji (raven 1) in zunanji komunikacijski sistem (nadrejeni ravni 3 in 4), da pa ima dramski model manjše število zaporednih semiotičnih ravni, saj izpade posredniški komunikacijski sistem (raven 2, "vrinjena « med ravni 1 ter 3 in 4 ).

Dramski komunikacijski model torej sestavljajo tri ravni:

Poš1/Pre1: dialoška komunikacija dramskih oseb, ki si izmenjujeta replike,

Poš3: idealni avtor, ki se obrača na Pre3, tj. idealnega poslušalca/bralca (kakršnega predvideva že sama struktura dramskega besedila oziroma ga vzpostavlja),

Poš4: empirični avtor dramskega besedila oziroma uprizoritve, ki sporoča, Pre4, tj. empiričnim bralcem oziroma gledalcem (uprizorjene) drame.

9 Z Aristotelovo opredelitvijo bi šlo za neposredno posnemanje s pomočjo gledališča (prim. Pavis, 1997, 444), pri čemer pa je dejanje v teh »dramskih « romanesknih pripovedih govorno dejanje.

10 V literarnoteoretskem oziru bi šlo tudi za radikalizacijo»dramskega pripovedovalca» (Kos, 2001, 105). 
Pripovedni komunikacijski model pa sestavljajo štiri ravni: dodan je posredniški komunikacijski sistem, kjer »fiktivni pripovedovalec komunicira s fiktivnim poslušalcem, in funkcija tega sistema je, da posreduje med zunanjim in notranjim sistemom, komentira, opozarja itd.« (Kralj, 1998, 26).

Pripovedni komunikacijski model torej obsega:

Poš1/Pre1: dialoška komunikacija pripovednih oseb,

Poš2: fiktivni pripovedovalec oziroma subjekt pripovedi, ki ta dialog posreduje in morda komentira Pre2, tj. fiktivnemu poslušalcu/bralcu,

Poš3: idealni avtor, ki se obrača na Pre3, tj. idealnega bralca (kakršnega predvideva oziroma vzpostavlja struktura pripovednega besedila),

Poš4: empirični avtor, ki sporoča Pre4, tj. empiričnim bralcem svojega dela.

Lado Kralj (1998, 25-26) na Pfistrov pripovedni komunikacijski model prenese Stanzlovo tipologijo pripovedovalca: neposredno dialoško komunikacijo pripovednih oseb posreduje Poš2 kot avktorialni (vsevedni ali skoraj vsevedni) pripovedovalec, lahko pa tudi kot prvoosebni, če sam predstavlja (tudi) eno od oseb v dialoški (notranji) komunikaciji med pripovednimi osebami.

Če pa na pripovedni komunikacijski model prenesemo trojno tipologijo pripovedovalca, kot jo zariše Janko Kos (2001, 103-105), se upošteva razlika med gramatikalno določenim pripovedovalcem (prvo-, drugo- in tretjeosebni), načinom govora (Platon, Aristotel; gl. op. 39; po Kosu gre za tipe: lirski, dramski in epski pripovedovalec) ter pripovedovalčevim odnosom do resnice in resničnosti oziroma "pogledom na svet« (avktorialni, personalni in virtualni pripovedovalec).

Tisti sodobni romani, ki poskušajo dosledno »citirati« e-poštno ali npr. internetnoklepetalniško komunikacijo, vzbujajo vtis dramske skripcije: pripoved gradi zaporedje zapisanih dialoških replik, kar pravzaprav prenavlja žanr pisemskega romana.

$\mathrm{V}$ dramski pripovedi stopa $\mathrm{v}$ ospredje monolog oziroma dialog pripovednih oseb, ki ni samo notranji, ampak ga lahko razumemo kot glasnega ali zunanjega. To se dogaja v mnogih pisemskih romanih /.../. Kjer dobijo pisma podobno vlogo kot dialog v dramskem dogajanju, so že primer dramske pripovedi; tu pripovedujejo zgodbo pisci pisem, ko stopajo med sabo v bolj ali manj napeta razmerja. Tudi dialoški romani, kot je Puigov Poljub ženske pajka, se z zunanjo dialoško obliko približujejo dramatiki. (Kos, 2001, 106)

$\mathrm{V}$ obravnavanih sodobnih romanih je tip pripovedovalca vsekakor dramski, vendar pripoved vzpostavlja tudi drobno razliko med »citatom« internetnega »klepeta« in »citatom « e-poštne izmenjave sporočil (pisem). Tisti sodobni romani, ki skušajo dosledno »citirati« internetno-klepetalniško komunikacijo (v kateri so 
replike krajše), so bliže dramski pripovedi dialoških romanov, tisti, ki skoraj dosledno "citirajo « e-poštno komunikacijo, pa pisemskim romanom: v njih je zaporedje replike sicer tudi kavzalno kontinuirano, so pa lahko tudi daljše in obsegajo dopisovalčevo (pripovedno-osebno) avtorefleksijo in poročanje o dogodkih, ki so se osebi zgodili zunaj dialoške komunikacije s prejemnikom njenega e-pisma, torej z epsko distanco $\mathrm{v}$ samem notranjem komunikacijskem okvirju in njegovim premim govorom: $\mathrm{v}$ pripovedovanjih (dveh ali več) oseb o sebi kot prvoosebnih pripovedovalcih. Res pa so ti podrejeni dramskemu pripovedovalcu oziroma posredniškemu komunikacijskemu okvirju.

\section{Intermedialni sodobni roman in postmoderno stanje: primer Glattaver}

Roman se zdi posebej dovzeten za tematizacijo sodobne medbesedilnosti in intermedialnega razmerja literature $\mathrm{z}$ elektronskimi mediji že po svojih »temeljnih" vrstnih opredelitvah: 1.) v tradicionalnejši opredelitvi skuša roman, iz epske domene javnega premaknjen $\mathrm{v}$ moderno zasebno, na nov način, zgodovinsko (časovno) vzpostavljati izgubljeno »totaliteto«(G. Lukács). In sodobnost? Načeloma »neskončni« postmoderni virtualni prostor, ki ga vzpostavljajo elektronski mediji, opredeljuje simultanost. V medmrežju »delujoči« posameznik je virtualna, znakovna prezenca, kar mu omogoča nenehno menjavo in tudi neskončni potencial (virtualnih) identitet. ${ }^{11}$ Virtualne identitete torej gradijo prostorski preskoki v nenehno ponavljano simultanost oziroma spacialnost. Kljub prevladi prostorskosti to seveda ne pomeni obnavljanja mitske »totalitete " v postmoderni dobi in v postmodernistični literaturi, ${ }^{12}$ saj so identitete poljubne, "v času « zamenljive in različne, torej razveljavljene v svoji resničnosti. Po drugi strani skrajno zasebna e-poštna komunikacija kot tudi »javnejše» spletne klepetalnice $\mathrm{v}$ časovno simultanost virtualnega prostora vendarle lahko vnašajo tudi sled napredovanja oziroma linearnega časa, saj virtualne identitete pri tem izdeluje tudi dialog, ta pa tudi v virtualni resničnosti vodi k razreševanju (komunikacijskega) konflikta ali vsaj $\mathrm{h}$ »karakternemu « napredovanju v gradnji virtualne identitete, tako da se elektronska komunikacija vendarle nanaša tudi še na moderno časovnost. »Izkušnja« postmodernosti, ki jo vsaj posredno tematizira sodobni roman s »citatnostjo« virtualnih medčloveških razmerij, se torej nanaša tako na mitsko kot na moderno izgubljeno »totaliteto«, ne da bi eno ali drugo seveda lahko »obnovil«. 2.) Aktualnejša vrstna

11 Ker elektronski mediji ne vzpostavljajo neposrednega stika, marveč »izkristalizirane verbalne znake«, se s tem zasenči socialne kategorije, na katerih oblikujemo svoje vzorce pripadnosti (Schmitz, v: Jones, 2001, 135).

12 »Postmodernizem /.../ postavlja pod vprašaj celo resničnost neposredne izkušnje, njeno gotovost v "prezenci«. To mu omogoča dvom o neposredni resničnosti samega jaza, subjekta, resničnosti jezika, v katerem govori, kajti vse to je lahko samo konstrukcija, katere resničnost je samo še navidezna /.../.« (Kos, 1995, 51) 
opredelitev romana je dialoškost, polifonija, konfrontacija »jezikov« (M. Bahtin), ki krožijo v skupnosti. Ta medbesedilnost se zdi ključni vidik tudi za tisti sodobni roman, ki »citira« in s tem tematizira e-poštno in internetno-klepetalniško komunikacijo, virtualnost identitet, tako tudi virtualnost »sočloveške« problematike in s tem ontološko negotovost sodobnega človekovega položaja.

Kot primer tovrstnega sodobnega romana je v nadaljevanju obravnavan popularni, v žanrski osnovi nekako ljubezenski, a v svoji intermedialni strukturi precej pomenljiv roman Proti severnemu vetru (Gut gegen Nordwind, 2006) Daniela Glattauerja. "Citat« e-poštnega sporočilnega niza je tu skoraj »absoluten«: obvladuje strukturo celotnega romanesknega besedila kot sporočila, $\mathrm{z}$ izjemo naslova in s komaj opazno sledjo (virtualnega) pripovedovalca (več o tem pozneje). Pripovedno besedilo romana torej obsega zgolj pisemsko dialoško komunikacijo iz zaporednih replik pošiljatelja in prejemnika $\mathrm{v}$ notranjem pripovednem komunikacijskem okvirju, kot da roman iz pripovednega preide $\mathrm{v}$ dramski komunikacijski model, bralca pa pri tem postavlja v vlogo voajerja pred gledališko »četrto steno« kot skrajni domet »odrske iluzije«. Sodobni »oder « je pri tem seveda virtualni prostor komunikacijske performativnosti v tehnološkem mediju zaslona oziroma e-pošte, ki jo posreduje zaslon. Idealni in fiktivni bralec (»gledalec«) je $\mathrm{v}$ ta intermedialno priklicani virtualni prostor kot imaginarni prostor literature umeščen kot molčeča oziroma nevidna (neidentificirana) sonavzoča »identiteta«.

Glattauerjev roman Proti severnemu vetru besedilo romana torej gradi s »citatom " naključno vzpostavljene, v izhodišču arbitrarne e-poštne komunikacije med »Emmi Rothner« in »Leom Leikejem«. Zgodbo vzpostavlja izključno rastoča interakcijska gradnja »Emmijine« in »Leove« virtualne identitete, česar se sogovornika tudi zavedata:

Naslednji dan

Ni zadeve

Draga Emmi, ste že opazili, da drug o drugem ne veva prav ničesar? Ustvarjava virtualne fantazijske podobe, izdelujeva iluzionistične fantomske slike. /.../ Ja, to, da budiva radovednost drugega /.../, imava za šport. /.../ (Glattauer, 2010, 23)

Čez 40 minut

RE:

/.../ Leo, bodiva vendar poštena: Za vas sem fantazijska podoba, resničnih pri tem je le nekaj črk, ki jih znate jezikovno-psihološko spraviti v zvenečo povezavo. /.../ (Glattauer, 2010, 54)

Zgodbo torej vzpostavlja rast vzajemne vednosti obeh pripovednih oseb, pogosto $s$ pisnim (samo)predstavljanjem osebe, nato tudi kratka, formalno prvoosebnopripovedna poročila o dogodkih ene in druge osebe, o srečanjih $z$ drugimi ljudmi zunaj virtualnega prostora. Resničnost teh poročil seveda ni (empirično) 
preverljiva, saj obstajajo le $\mathrm{v}$ govorici oziroma pisavi. Kljub temu pa tematizirano razmerje med virtualno in empirično resničnostjo obeh oseb vzbuja napetost $\mathrm{z}$ obeh izhodišč: virtualne in empirične resničnosti. Empirična resničnost je za obe osebi očitno nezadostna (zunanja socialna forma eksistence, kot sta npr. zakonska zveza ali partnersko razmerje, ne zadovoljuje notranjega sveta ne ene ne druge osebe; subjekt ene in druge osebe se vzpostavlja v nezadoščujočem razmerju s »svetom«; znak za to občutenje manka je ne nazadnje »beg « $\mathrm{v}$ virtualni sočloveški prostor, $\mathrm{v}$ virtualno identiteto in v dopisni »flirt«). Obenem je seveda nezadostna tudi virtualna identiteta, od katere sogovornik (najprej Emmi, nato Leo) terja preverbo njene avtentičnosti $\mathrm{v}$ empirični resničnosti (fizične, telesne prezence). Nepresegljiva napetost med obema resničnostima rezultira $\mathrm{v}$ popolno ontološko negotovost, zaradi česar se komunikacija zlahka prekine oziroma razvrednoti, s tem pa izbriše tudi (virtualni) identiteti obeh pripovednih oseb. Ko se komunikacija konča, pripovedni osebi, kakršni se predočata bralcu in druga drugi, več ne obstajata.

Kratka prvoosebnopripovedna poročila o dogodkih zunaj virtualnega prostora, pogosto prepletena $\mathrm{z}$ (avto)refleksijo prvoosebnega pripovedovalca $\mathrm{v}$ notranjem komunikacijskem modelu, izražata npr. »Emmijino« pismo:

\section{Čez 6 ur}

RE:

Tako, Leo. Sedim v svoji sobi, Bernhard še dela, Fiona prenočuje pri prijateljici, Jonas spi (z dvema zoboma manj), Wurlitzer se baše s pasjo hrano /.../. (Glattauer, 2010, 134)

ali Leovo pismo:

Čez štiri ure

RE:

Draga Emmi iz zunanjega sveta, uživam v vaših mejlih. /.../ Ne bom vsiljivec $\mathrm{v}$ družini Rothner, Emmi, okupiram samo na zaslonu! /.../ Posebej očarljivo se mi zdi, da se igrate $\mathrm{z}$ mislijo, da bi me spravili skupaj s kakšno žensko. Kakšne ženske so mi všeč? Ženske, ki so videti tako, kot vi pišete, Emmi. In ženske, pri katerih slutim možnost, da bom enkrat tudi njihov notranji svet, ne samo zunanji. /.../ Danes se dobim še s sestro Adrienne. Vesela bo zame, da sem se še enkrat uspešno razšel z Marlene. /.../. (Glattauer, 2010, 136-7)

Zgradbo te zgodbe pa vzpostavlja časovno zaporedna izmenjava e-poštnih sporočil oziroma pisem, ki se kavzalno navezujejo na vsebino predhodnih in s tem vzbujajo iluzijo kontinuitete (ta je v virtualnem prostoru sicer nenehno ogrožena in s tem relativizirana).

Razmerje med pripovednim in dramskim komunikacijskim modelom $\mathrm{v}$ Glattauerjevem romanu aktualizira že ponovna uporaba značilnosti pisemskega 
romanesknega žanra: »citati« e-poštnih pisemskih sporočil spominjajo na dramatično sukcesivnost in suspenz, kot ga vzpostavlja pisemski romaneskni žanr. Izmenjava sporočil pa za razliko od pisemskega romana zunanje-formalno spominja na izmenjavo replik v dramskem dialogu: na »objektivirano subjektivnost« (Kos, 2001, 109), ki jo vzpostavlja govor (izključno) dramskih oseb: replike so odprtejše od pisemskih in krajše. Posamezno pisemsko sporočilo je sicer lahko obsežnejša (avto)refleksija oziroma pripoved pošiljatelja o sebi; lahko gre tudi za lagodnejši tempo razreševanja manj usodnih nesporazumov, ki jih ustvarjajo komunikacijski »šumi« pri poskusu usklajevanja virtualne identitete sodopisovalca $\mathrm{z}$ njegovo realno identiteto:

Naslednji dan

Zadeva: ???

Draga gospa Rothner, ste užaljeni? Poglejte, saj vas vendar ne poznam. Kako naj bi vedel, koliko ste stari? Morda ste 20, morda 60. /.../ (Glattauer, 2010, 18)

Pri tem pa lahko nesporazum naraste tudi v »dramatični« konflikt: v trenutkih, ko se medčloveško razmerje $\mathrm{v}$ dopisovanju zaostri, začne delovati kot dramski prizor, strukturiran v sukcesivnem razreševanju konflikta. Tempo izmenjave sporočil (eksplicitno razberljiv v zapisu časovnih razmerij med dvema replikama oziroma $\mathrm{v}$ zabeležbi časa odgovora) pri tem skokovito naraste.

Izmenjujeta se torej (a) bolj pripovedna, v počasnejšem ritmu izmenjave nizana (gl. zgoraj) in (b) bolj dramska strukturacija zaporedja replik:

Čez pet minut

Re:

Torej bi prevarali svojega moža?

Čez minuto

Re: Kdo je to rekel?

Čez 40 sekund

Re:

To berem iz vaših besed.

Čez 35 sekund

Re:

Pazite, da ne preberete preveč.

Čez 2 minuti

Re:

Kaj vam manjka pri vašem možu? (Glattauer, 2010, 84)

Dramatičnost vzpostavlja napetost med »razbrano« situacijo »Emmijine» virtualne identitete in življenjsko situacijo »Emmijine« realne identitete. Na sugerirano vprašanje, katera od identitet je bolj avtentična, roman ne more odgovoriti, saj njegovo 
strukturo določa skriti oziroma (skoraj) odsotni »dramski« pripovedovalec, katerega naloga je zgolj »citirati« e-poštni dialog pripovednih oseb, zato ne more komentirati oziroma presojati o prevladi virtualnega ali realnega. Celo »Emmijino « poročilo o vdoru realnega v njen odnos do »Lea« (pripadnost soprogu kljub ljubezni do virtualnega Lea prepreči, da bi avtentičnost »Leove« virtualne identitete preverila $\mathrm{z}$ realnim srečanjem) piše virtualna »Emmi « v virtualnem prostoru, tako da resničnosti njenih argumentov ni mogoče preveriti. Edini implicitni komentar skritega fiktivnega pripovedovalca je lahko samo tesnobo vzbujajoča ontološka negotovost. Vednost skritega oziroma skoraj odsotnega pripovedovalca je torej v tem, da ne ve, s čimer se bliža položaju virtualnega pripovedovalca (Kos, 2001). ${ }^{13}$ Ker besedilo romana tematizira sodobna medčloveška razmerja oziroma komunikacijo tako, da se nanaša na enega najobičajnejših načinov komunikacije v postmoderni, torej na e-poštno komunikacijo v virtualnem prostoru, se ta tesnobo vzbujajoča ontološka negotovost razširja na sodobno situacijo, v kateri se lahko prepoznava realni bralec.

\section{Za sklep: Jakobsonov komunikacijski model in intermedialnost sodobnega romana}

Sodobno romaneskno nanašanje na e-poštno komunikacijo kot sodobna možnost intermedialnosti posebej poudarja interakcijo med medijem in sporočilom: reflektira McLuhanovo tezo: »medij je sporočilo«, saj vsaj v notranjem pripovednem komunikacijskem okvirju v celoti, v zunanjem pa vsaj deloma prevprašuje prav vseh šest dejavnikov Jakobsonovega komunikacijskega modela (Jakobson, 1996, 153).

Kontekst: v zunanjem komunikacijskem okvirju roman tematizira e-poštno komunikacijo kot enega najpogostejših načinov vzpostavljanja medčloveških razmerij v sodobni resničnosti, v notranjem komunikacijskem okvirju pa besedilo romana ustvarja skupno resničnost virtualnega prostora, katerega konvencije morajo za uspešno komunikacijo sprejeti oziroma se nanje nanašati vsi pošiljatelji in prejemniki, $\mathrm{v}$ tem primeru pripovedne osebe.

\section{Pošiljatelj in}

prejemnik sporočila: $\mathrm{v}$ tej intermedialni strukturi romana je dominantni oziroma »izvorni« medij še vedno tradicionalni medij moderne literature, tj. knjižni natisnjeni zapis, ki fiksira strukturo besedila, s čimer se ohranja avtorska funkcija nadzora nad bralčevim branjem: v zunanjem pripovednem okvirju se vloga realnega avtorja in

13 Ta tip pripovedovalca, značilen za postmodernistično pripoved, »se lahko na videz postavlja v vlogo avktorialnega ali personalnega pripovedovalca, vendar tako, da bo bralec vedel /.../, da je to samo igra, pretvarjanje in simulacija. V njegovi pripovedi ne bo nobene trdne resnice, /.../, pa tudi ne izkustva subjektivne zavesti, ki bi ji lahko pripisali veljavo nečesa empirično resničnega /.../.« (Kos, 2001, 105) 
bralca ne prevprašujeta. Pač pa se prevprašuje $\mathrm{v}$ posredniškem komunikacijskem okvirju vloga fiktivnega pripovedovalca (in njegovega prejemnika), saj je fiktivni pripovedovalec, bližajoč se virtualni pripovedni poziciji, skrit oziroma skoraj odsoten, $s$ tem pa se intenzivno prevprašuje tudi vloga pošiljatelja in prejemnika v notranjem komunikacijskem okvirju, tj. med samimi pripovednimi osebami. Pripovedovalčeva strukturna skritost sporočilo vzpostavlja kot »citirani« niz e-poštnih sporočil pripovednih oseb kot dveh prvoosebnih pripovedovalcev, ki pa sta zaradi svoje prezence zgolj $\mathrm{v}$ replikah tako rekoč istovetna $\mathrm{z}$ dramskima osebama; ne nazadnje jima virtualnost prostora njunih izjavnih situacij, vzpostavlja virtualno identiteto in $\mathrm{s}$ tem potencial »maske« oziroma vloge. $V$ virtualnem prostoru stika pripovedne osebe svojo identiteto - sebi, »nevidnim« sogovornikom in bralcu - vzpostavljajo izključno z zapisano jezikovno izjavo, ki je ni mogoče empirično preveriti, njuna identiteta pa je zato a priori in nepresegljivo virtualna. $S$ tem pripovedni osebi v sodobni medčloveški (e-poštni) komunikaciji zastavljata vprašanje o suverenosti pošiljatelja in prejemnika: oba sta $\mathrm{v}$ notranjem komunikacijskem okviru pravzaprav poistovetena s samim sporočilom, saj se prezentirata izključno kot zapisana sporočila. Kolikor se sporočilo nanaša na pošiljatelja oziroma prejemnika, se torej nanaša samo nase oziroma na svojo strukturo, s tem pa postane vsako sporočilo avtoreferencialno. Dialoška celota, ki poteka v virtualnem prostoru, pa s tovrstno komunikacijo vzpostavljena medčloveška razmerja spreminja v nezavezujoča, arbitrarna ali celo »literarno« zgolj igro: kot sugestijo postmoderne situacije in njene ontološke negotovosti.

Kod: naravni jezik, ki ga uporabljajo pošiljatelji in prejemniki v notranjem komunikacijskem okvirju, ni problematiziran. Vendar pripovedne osebe komunicirajo izključno pisno in pri tem ne vidijo sogovornikovih telesnih znakov (gestike in mimike) ali slišijo zvočnih intonacij govora, obenem pa tudi nimajo nobene skupne »zgodovine« oziroma preddopisovalnega (realnega) poznanstva drug drugega. Zato ne morejo zanesljivo »razbrati« pomenskih nians, konotacij, ki lahko bistveno zaznamujejo sporočilo. Posledično velik del komunikacije aktivira metajezikovno funkcijo: zaznava komunikacijske »šume« in preverja, ali je bilo sporočilo pravilno razumljeno.

Sporočilo: v notranjem komunikacijskem okvirju je zgrajeno v konvencionalni obliki e-poštnega sporočila. To naj vzbuja vtis vsakdanje komunikacije. V posredniškem pripovednem okvirju zato sporočilo prevlada nad dejavnikom pošiljatelja kot fiktivnega pripovedovalca, saj ta šele s svojim samoizbrisom vzpostavlja svojo (»nevidno«) navzočnost. Besedilo romana se po svoji strukturi medbesedilno nanaša na konvencije dramske strukture: ob didaskalijah dramo sestavlja izključno govor dramskih oseb, členjen v replike. Nekaj formalnih konvencij e-poštne komunikacije (»od: ...«, »za: ...«, »Re:«) se bliža vlogi didaskalij v tem, da identificira (pisemsko) 
repliko. Konvencionalni zapis časa odpošiljke sporočila v e-pošti pa je znak časovnega napredovanja prikazane komunikacije: s tem, ko »citira e e-poštno obliko sporočila, dejansko pomeni »vstop na sceno « oziroma vsakič novo konfiguracijo »dramskih oseb « na (virtualnem) prizorišču komunikacije in se tako približuje dramski didaskaliji. Res pa je, da prav s temi »didaskalijami« skriti pripovedovalec diskretno nastopi v neskritost: namesto avtentičnega »citata« časa, ki ga po konvenciji vsebuje e-poštno sporočilo (npr. "poslano: 9. 4. 2011, 23.10«), se časovno zaporedje replik prezentira kot pripovedovalčev implicitni komentar (»Čez 35 sekund«). Akceleracija v izmenjavi replik "pripoveduje o konfliktni dramatičnosti njihove vsebine za dialoška partnerja. Sporočilo celotnega besedila romana je torej zgrajeno $\mathrm{v}$ tenziji med pripovednim in dramskim komunikacijskim modelom. S tem, kot rečeno, pripovedni osebi deloma poistoveti s samimi njunimi replikami, torej s samim sporočilom (gl. 2 in 3), tako da prevprašuje tudi dejavnik sporočila oziroma ga $\mathrm{v}$ nakazanem posredniškem in $\mathrm{v}$ očitnem notranjem komunikacijskem okvirju privilegira na račun razvrednotenja pomena pošiljatelja in prejemnika $\mathrm{v}$ (virtualni) komunikaciji sodobnih medčloveških razmerij. Problematizacijo sodobnih identitet si dejavnik sporočila deli zlasti $\mathrm{z}$ dejavnikom stika, ki implicira medij.

Stik (z implikacijo medija) je najbolj eksplicitno prevpraševani dejavnik: medijska specifika »citirane« e-poštne komunikacije v notranjem komunikacijskem okvirju (med pripovednimi osebami) aktivira naravnanost sporočila k stiku oziroma fatično funkcijo. V pripovedovani resničnosti, kot jo vzpostavlja tehnološki medij osebnega računalnika oziroma (ožje) zaslona, je prostor stika torej virtualni prostor, s tem pa v notranjem okviru pripovedne komunikacije relativizira »resničnost« same komunikacije in v tem, notranjem okviru tudi prav vse dejavnike komunikacijskega modela izpostavi ontološki negotovosti.

Zato je osrednja tema tovrstnega intermedialnega sodobnega romana sodobna komunikacija in njena (ne)možnost vzpostavljanja medčloveških razmerij, potrditev subjektivne resničnosti in vzpostavljanja temeljnih vrednot kot resnic. Intermedialno predstavljena sodobna komunikacija v romanu tako postane simbolna makrostruktura pripovedi za ontološko prevpraševanje resnice in resničnosti, identitete udeležencev komunikacije in s tem človekovega položaja v sodobnem "prostoru «. ${ }^{14}$ To omogoča dosledno intermedialno »citatno" nanašanje na e-poštno komunikacijo, s čimer se tako strukturirano literarno sporočilo kot besedilna celota romana nanaša samo nase oziroma postane literarno sporočilo ${ }^{15}$ postmodernega romana.

14 »Relativizacija resnice, legitimizacija paradoksa, ontološka desubstancializacija - vse to so torej /.../ globlja določila duhovnozgodovinske podlage dobe.« (Virk, 2000, 35)

15 Povzeto po J. Cullerju, U. Ecu, A. Garcia-Berrii idr., M. Juvan $(2003,83)$ eno od dveh temeljnih tendenc literarne rabe jezika definira kot »težnjo $k$ besedilni avtoreferencialnosti, tj. $k$ dejstvu, da je bralec pozornejši na strukturne homologije, na igro $\mathrm{z}$ rekurentnimi oblikami in dvoumnimi pomeni 


\section{Literatura}

Biti, V., Pojmovnik suvremene književne i kulturne teorije, Zagreb, 2000.

Fischer-Lichte, E., Estetika performativnosti, Ljubljana, 2008.

Glattauer, D., Proti severnemu vetru, Ljubljana, 2010.

Hartling, F., The Digital Author? Authorship in the Digital Era, v: V. Matajc, G. Troha (ur.), Primerjalna književnost (special issue), 32, 2009, 199-208.

Jakobson, R., Lingvistika in poetika, v: R. Jakobson, Lingvistični in drugi spisi, Ljubljana, 1996, 147-190.

Johansen, J. D., Literary Discourse: a Semiotic-Pragmatic Approach to Literature, Toronto, 2002.

Jones, S. G., Virtuelna kultura (Biblioteka XX vek, 15), Beograd, 2001.

Juvan, M., Literarna veda v rekonstrukciji, Ljubljana, 2006.

Juvan, M., On Literariness: From Post-Structuralism to Systems Theory, v: S. Tötösy de Zepetnek (ur.), Comparative Literature and Comparative Cultural Studies, West Lafayette, 2003, 76-96.

Kos, J., Literarna teorija, Ljubljana, 2001.

Kos, J., Postmodernizem (Literarni leksikon, 43), Ljubljana, 1995.

Kralj, L., Teorija drame (Literarni leksikon, 44), Ljubljana, 1998.

Pavis, P., Gledališki slovar (Knjižnica Mestnega gledališča ljubljanskega, 124), Ljubljana, 1997.

Pfister, M., Das Drama. Theorie und Analyse, München, 1988.

Rajewsky, I. O., Intermedialität, Tübingen, 2002.

Strehovec, J., Besedilo in novi mediji, Ljubljana, 2007.

Virk, T., Strah pred naivnostjo, Ljubljana, 2000. 
Vanesa Matajc

\section{Literature and e-Communications: The Intermediality of the Postmodern Novel}

Keywords: intermediality, e-communications, postmodern novel, narrative model of communication, Daniel Glattauer

The article addresses the question of intermediality, which fundamentally defines the narrative structure in some postmodern novels, whose narrations are entirely structured as "quotation" mediated in the form of e-mail. This method of narration, which explicitly "quotes" the direct speech spoken (and also written) by two or more fictional characters (i.e., dialogic partners) is reminiscent of drama, or the play, as a model of communication. By occupying the narrative structure of these postmodern novels, drama as a model of communication cancels out the authority of the fictional narrator, who may make comments on the "quoted" e-mails exchanged, giving the fictional recipient the assurance of some sense of transcendence in this dialogue. However, the very position of this hidden fictional narrator can serve as an indirect comment on the consequences of widespread e-mail communication, which takes place in virtual space. The electronic media that make this kind of communication possible reestablish virtual space as specific conditions of contact through which the addresser and addressee appear as virtual identities. The virtual identities of the two or more fictional characters that create the narration through successive e-mail exchanges begin to be confronted with the presupposed "real" identity of their dialogic partners. This anxious tension between the "real" and "virtual" presences leads to ontological uncertainty, which is considered a basic characteristic of postmodern literature. From this perspective, the intermedial narrative structure of some postmodern novels, which "quote" communication in the form of e-mail, perfectly confirms McLuhan's postulate that the medium is the message. 